\title{
The Relevance of Social Responsibility and Financial Performance of Listed Companies
}

\author{
Jingwen $\mathrm{Mi}^{1}$, Shaoyan Jiang ${ }^{1}$, Xiaohui Tao ${ }^{1} \&$ Wanwan $\mathrm{Hu}^{1}$ \\ ${ }^{1}$ International Business Institute, Jinan University, Zhuhai, China \\ Correspondence: Shaoyan Jiang, International Business Institute, Jinan University, Zhuhai, China.
}

Received: March 29, 2018 Accepted: April 20, 2018 Online Published: May 14, 2018

doi:10.5539/jms.v8n2p40 URL: https://doi.org/10.5539/jms.v8n2p40

\begin{abstract}
This paper uses the data of Chinese listed companies from 2014 to 2016 as a sample to discuss the relationship between corporate social responsibility and financial performance. At the same time, it analyzes the regulatory role of corporate scale and growth opportunities in the impact of social responsibility on economic performance. The study finds that there is a significant positive correlation between social responsibility and financial performance. The scale of the enterprise reverses the impact of social responsibility on financial performance, and growth opportunities do not regulate the impact of social responsibility on financial performance.
\end{abstract}

Keywords: corporate social responsibility, financial performance, growth opportunities, corporate scale

\section{Introduction}

In 2016, after Samsung Electronics' Galaxy Note7 mobile phone was released, more than 30 explosion accidents caused by battery defects occurred worldwide. Product quality and quality supervision issues have attracted the attention of the whole society. At the same time, the company's stock price plunged 7\% on September 12th, which has been the largest drop since 2012. On July 20th of the same year, China's first case of air pollution litigation sentenced the defendant Zhenhua Co., Ltd. to compensate for the loss caused by excessive discharge of pollutants by RMB 21,986,600. This lawsuit warns that the listed companies should establish the bottom line of corporate social responsibility. In recent years, a series of major social responsibility events have become the focal point of the debate. The people and government have continuously raised their awareness of corporate social responsibility.

The corporate social responsibility report issued by Chinese enterprises started late, but under the influence of various policies and regulations, the research on social responsibility has developed rapidly. The number of companies that publish social responsibility reports in China has increased year by year (Zhang, 2014). In 2008, the Shenzhen Stock Exchange and the Shanghai Stock Exchange both required listed companies to disclose relevant social responsibility reports in accordance with the provisions of the Social Responsibility Guidelines; in 2016, the State-owned Assets Supervision and Administration Commission of the State Council issued the "Guiding Opinions on Better Performing Social Responsibility of State-owned Enterprises"; in the same year, Shanghai held a forum on social responsibility for foreign-funded enterprises for the first time, which is of great significance to the construction of social responsibility in related industries in China. More and more listed companies publish social responsibility reports to meet the requirements of authoritative departments and the public's demand for corporate social responsibility information disclosure. In the fierce market competition environment, the company pays more attention to the corporate social responsibility report and invests a lot of resources for it. Managers believe that corporate social responsibility activities will create a good social image for the company and thus promote company performance (Luo, 2009; Zhang, 2012). However, empirical studies by Wang \& Song (2007) find that there is a significant negative correlation between corporate social responsibility performance and financial performance.

This paper designs and uses relevant indicators to study the relationship between corporate social responsibility and corporate profits, growth opportunities, and firm size of 451 sample listed companies, and discusses the impact of corporate social responsibility on corporate performance. In the past, scholars paid less attention to business growth opportunities, and usually just used the company scale as a control variable. This paper uses both as control variables. Through analysis, we find that there is indeed a significant positive correlation between corporate social responsibility and corporate performance. The better the performance of social responsibility, 
the higher the company's financial performance.

\section{Literature Review}

Corporate Social Responsibility (CSR) refers to the company's responsibility to its customers, suppliers, government, employees, and other stakeholders as well as the environment when it undertakes economic responsibilities to its shareholders. From the perspective of corporate social responsibility, companies should not unilaterally pursue profit maximization, but should perform appropriate social responsibilities and obligations and seek a balance between social responsibility and corporate development. Scholars mainly study social responsibility from two aspects. One of them is to study the motives for disclosure of social responsibility reports, such as supervisory motivation and stakeholder motivation (Kotonen, 2009), as well as lower financing cost motivation ( $\mathrm{Li}, 2013 ; \mathrm{Bi}, 2015)$. On the other hand, scholars also consider the consequences of fulfilling social responsibilities, which mainly refers to the relationship between social responsibilities and corporate performance. The study of the relationship between the two has not reached a consensus yet.

Most studies support a positive relationship between corporate social responsibility and corporate performance. Chi (2011) analyzes the financial data of some non-listed companies from the perspective of stakeholders and concludes that financial performance has a positive correlation with the contribution of stakeholders (suppliers and shareholders). Liu \& Wang (2012) adopt corporate social responsibility rating data and find that companies that perform well in fulfilling corporate social responsibility can effectively reduce the company's capital constraints as well as the company's development resistance, and improve corporate image. Cheng (2014) finds that corporate social responsibility can reduce agency costs and improve financial performance.

Some studies believe that there is a negative correlation between corporate social responsibility and corporate performance. Eunice (2014) finds that corporate social responsibility will lead to unnecessary cost expenditures. These costs will cause companies to be at a disadvantage in the fierce market competition environment. Seriously, it will result in that companies are difficulties in surviving. Zhong (2013) believes that China's current relevant system is still not perfect, and when companies undertake social responsibilities, they will limit their own development and will undermine the competitiveness of enterprises. Some scholars use the long- and short-term methods of empirical research and find that there is a short-term negative correlation and long-term positive correlation between corporate social responsibility performance and corporate performance. For example, the research of Wen\& Fang (2008) point out that the social responsibility variables of Chinese listed companies have negative impact on current financial performance. In the long run, there is a positive relationship between corporate social responsibility performance and financial performance.

In summary, due to the differences in data sources, variable selection, analysis methods, and applied theories, the correlation between corporate social responsibility and financial performance can be roughly divided into two factions: One school of scholar support there is a positive correlation between the two variables, and another school of scholars hold the idea that there is a negative correlation between them. At the same time, there are a small number of scholars who argue that there is no direct correlation between them (Waddock, 2015). Overall, the number of scholars who support the positive correlation between the two accounts for the majority (Ren Yuyu, 2017; Wang, 2011). This paper attempts to establish a linear regression model for 451 Chinese listed companies and discusses the relationship between corporate social responsibility information quality and corporate performance.

\section{Hypothesis}

\subsection{Social Responsibility and Financial Performance}

According to the stakeholder theory, companies engaging in social responsibility activities can enhance the company's relationship with stakeholders, establish good public relations, reduce transaction costs, and ultimately improve corporate performance. When the company performs well in fulfilling its social responsibilities, it can meet the requirements of stakeholders such as shareholders, customers, governments, employees, and the community. This will help the company to gain a long-term competitive advantage. When the company fails to fulfill its social responsibilities, it cannot meet the demands of stakeholders other than shareholders, which will cause market concerns, increase the company's business risks, and even lead to losses (Bi, 2015). Yin (2014) conducts research on non-financial A-share listed companies from 2009 to 2010 and concludes that corporate social responsibility is significantly positively correlated with corporate financial performance. Based on the above analysis, this paper proposes the following assumptions:

H1: There is a significant positive correlation between corporate social responsibility and financial performance in China. 


\subsection{The Regulation Effect of Corporate Growth Opportunities Between Social Responsibility and Financial Performance}

This article refers to the research of Zhang (2016) and uses the average annual intangible assets to measure business growth opportunities. This article defines intangible assets as assets that have no physical form but can be used by the company for a long time, such as patents, non-patent technology, copyrights, trademark rights, land use rights, goodwill, etc. (Andonova, 2016; Shi, 2000). According to the theory of resource dependence, the differences in corporate resources determine the performance of the firm to a large extent, especially the differences in intangible resources, because intangible resources are often difficult to be imitated and duplicated by other competitors (Nanggong, 2016). Chen (2012) research further shows that corporate social responsibility will indirectly affect corporate competitive advantage through the intermediary role of corporate intangible resources, and long-lasting competitive advantages have a positive impact on corporate performance (Zeng, 2012). Based on the above analysis, this paper proposes the following assumptions:

$\mathrm{H} 2$ : Corporate growth opportunities are adjusting the impact of social responsibility on financial performance.

\subsection{The Regulatory Effect of Corporate Size Between Social Responsibility and Financial Performance}

In the study of social responsibility report and corporate performance, most scholars choose to analyze the scale of the company as a control variable. They approve of the idea that when the company grows in size, it will expand the scale of production, reduce the cost of the unit product and increase the company's sales profit rate, which ultimately contributes to the improvement of financial performance (Jiang, 2011; Marc, 2012). At the same time, the larger companies are more likely to receive the attention of the media and the government. When companies fail to perform their social responsibilities well, they will damage the company's image and reputation. Therefore, large-scale companies tend to fulfill their social responsibilities (Xia, 2016). Maintaining a positive attitude will help realize its own sustainable development, gain investors' favor and improve financial performance (Bi, 2015). Zhang (2011) takes China's listed companies as the research object and regards the enterprise scale as a control variable to studies the relationship between corporate social responsibility and financial performance. She points out that corporate performance is affected by the size of the company. Based on the above analysis, this paper proposes the following assumptions:

H3: The size of the business is adjusting the impact of social responsibility on financial performance.

The theoretical model of this paper is shown in Figure 1.

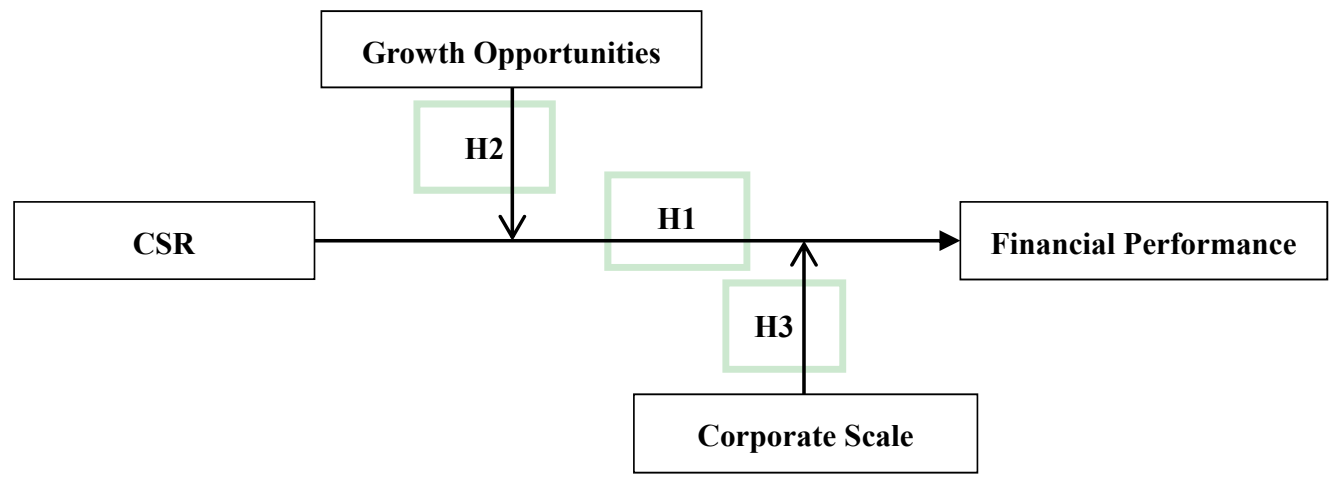

Figure 1. Theoretical model

\section{Research Design}

\subsection{Sample Selection and Data Sources}

This article uses the listed company that discloses social responsibility information for three consecutive years from 2014 to 2016 as the initial sample. Referring to the existing research, because the financial statement system of financial companies is different from other companies, we have excluded financial companies and deleted some samples with incomplete data information. The final sample of the study was 1353 samples of 451 Chinese listed companies.

The financial data in this article is mainly derived from the China Stock Market Financial (CSMAR) Database, which is the largest and most accurate financial and economic database in China at present; and some of the 
financial data that are lacking in the CSMAR Database are collected in the company's annual report on the CNINFO website. This website is the information disclosure website designated by the China Securities Regulatory Commission.

The quality score data of the listed company's social responsibility report comes from the third-party organization of China's corporate social responsibility rating - Runling Public Welfare Consulting Co., Ltd. (hereinafter referred to as RLCCW). The RLCCW scores the social responsibility report issued by listed companies in China. Some scholars have adopted this rating result, such as Jiang Yanjun (2011) and Yu Hongyan (2015). The score is based on structured expert scoring, whose full score is 100 points.

\subsection{Variable Design}

(1) Explained variable

Financial performance indicators. This article refers to Qi Wenhao's (2013) research method and uses return on total assets as an indicator of corporate performance to study the relationship between social responsibility and corporate performance. The return on total assets of the enterprise reflects the comprehensive utilization effect of the total assets of the company. The higher the total return on assets, the better the effect of the total assets' utilization and the better the performance of the enterprise.

(2) Explanatory variables

Corporate social responsibility. This paper uses the social responsibility report rating scores of RLCCW institutions, which receives increasing social recognition as the measure of social responsibility performance. The scoring system has absorbed the Sustain Ability report evaluation framework, the Dow Jones Sustainability Index (DJSI) evaluation system, and the international authoritative social responsibility standard ISO26000 and other international mainstream social responsibility reporting standards. Therefore it has certain compatibility. Referring to Bi Jinling's (2015) study, the logarithm of this score is used in this paper to meet the requirement of normal distribution of variables in the regression analysis.

(3) Moderating variables

Growth opportunities. This article defines the intangible assets of a company as the sum of the resources owned by the company that exist objectively and have no fixed form, which can create value for the company (Chen, 2012). According to the study of Zhang (2016), we use the natural logarithm of intangible assets to measure the growth opportunities of the company.

Business scale. According to the usual research, scholars usually use the total assets, sales revenue and number of employees to measure the size of the company. Considering that the sales revenue and the number of employees are easily affected by accidental factors such as the economic cycle, this paper uses the end-of-year total assets logarithm to measure the size of the company.

(4) Control variables

In past research, it was found that the nature of the company's equity, the proportion of the largest shareholder, the sustainable growth rate, the year, and the industry, etc., will all have an impact on the assumption of social responsibility and corporate performance, so this paper selects them as control variables. Table 1 describes the variables.

Table 1. Variable definition table

\begin{tabular}{|c|c|c|c|c|}
\hline Type & Name & & Symbol & Definition \\
\hline Explained variables & Return On Total Assets & & ROA & Net profit/average balance of total assets \\
\hline Explanatory variables & Social Responsibility & & CSR & Social responsibility report score from RLCCW \\
\hline \multirow{2}{*}{ Moderating variables } & Growth Opportunity & & Grow & LN(Total annual intangible assets) \\
\hline & Corporate Scale & & Size & LN(Annual average total assets) \\
\hline \multirow{5}{*}{ Control variables } & Nature Of Equity & & Own & $\begin{array}{l}\text { Dummy variables: state-owned and state-owned holdings } \\
1 \text {, others } 0\end{array}$ \\
\hline & $\begin{array}{l}\text { Proportion Of The } \\
\text { Shareholder }\end{array}$ & Largest & Firs & $\begin{array}{l}\text { The number of shares held by the largest shareholder/total } \\
\text { share capital }\end{array}$ \\
\hline & Sustainable Growth Rate & & SGR & $\begin{array}{l}\text { Return on assets* Revenue retention /(1-Return on assets* } \\
\text { Revenue retention) }\end{array}$ \\
\hline & Year & & Year & Virtual variables \\
\hline & Industry & & Ind & Virtual variables \\
\hline
\end{tabular}




\subsection{Research Model}

In order to verify the hypotheses proposed in the paper, the model constructed is as follows.

Model 1:

$$
R O A_{i t}=\alpha_{i t}+\beta_{1} \times C S R_{i t}+\beta_{2} \times O w n_{i t}+\beta_{3} \times \text { Firs }_{i t}+\beta_{4} \times S G R_{i t}+\beta_{5} \times \text { Year }_{i t}+\beta_{6} \times \text { Ind }_{i t}+\mu_{i t}
$$

Model 2 and Model 3 are set after considering the interaction of growth opportunities, company size and corporate social responsibility:

Model 2:

$$
\begin{gathered}
\operatorname{ROA}_{i t}=\alpha_{i t}+\beta_{1} \times \operatorname{CSR}_{i t}+\beta_{2} \times O \text { Own }_{i t}+\beta_{3} \times \text { Firs }_{i t}+\beta_{4} \times S G R_{i t}+\beta_{5} \times \text { Year }_{i t}+\beta_{6} \times \operatorname{Ind}_{i t}+\beta_{7} \\
\times \text { Grow }_{i t}+\beta_{8} \times \text { Size }_{i t}+\mu_{i t}
\end{gathered}
$$

Model 3:

$$
\begin{aligned}
R O A_{i t}=\alpha_{i t}+\beta_{1} & \times \operatorname{CSR}_{i t}+\beta_{2} \times O \text { Wn }_{i t}+\beta_{3} \times \text { Firs }_{i t}+\beta_{4} \times S G R_{i t}+\beta_{5} \times \text { Year }_{i t}+\beta_{6} \times \operatorname{Ind}_{i t}+\beta_{7} \\
& \times \operatorname{Grow}_{i t}+\beta_{8} \times \text { Size }_{i t}+\operatorname{Grow}_{i t} \times \operatorname{CSR}_{i t}+\operatorname{Size}_{i t} \times \operatorname{CSR}_{i t}+\mu_{i t}
\end{aligned}
$$

In the formula, $\alpha$ denotes a constant term, $\beta$ denotes a regression coefficient, $\mu$ denotes a random disturbance term, subscript $i$ denotes an $i^{\text {th }}$ company and $t$ denotes $t$ period.

\section{Empirical Test and Result Analysis}

\subsection{Descriptive Statistics}

Table 2. Descriptive statistics of variables

\begin{tabular}{llllll}
\hline Variable & Min & Max & Mean & Standard Deviation & N \\
\hline Return On Total Assets & -0.6513 & 0.3900 & 0.0388 & 0.0669 & 1353 \\
Social Responsibility & 19.9764 & 87.9478 & 42.2623 & 1.1523 \\
Growth Opportunity & 7.4185 & 24.7015 & 17.9039 & 2.3272 & 1353 \\
Corporate Scale & 19.5522 & 28.5087 & 23.2771 & 1.4519 & 1353 \\
Nature Of Equity & 0 & 1 & 0.68 & 0.67 & 16.18 \\
Proportion Of The Largest Shareholder & 5.02 & 95.95 & 40.95 & 0.1012 \\
Sustainable Growth Rate & -1.0446 & 0.5319 & 0.0285 & 1353 \\
\hline
\end{tabular}

Descriptive statistical indicators are shown in Table 2. According to Table 2, the minimum return on total assets of sample listed companies is $-65.13 \%$, and the maximum value is $39 \%$, indicating a large range of changes. This shows that the financial performance of sample companies is significantly different. The maximum and minimum values of the social responsibility report quality scores also differ greatly, with the average value being low, reflecting that there are great differences in the performance of social responsibility of listed companies in China. Overall, listed companies have insufficient awareness of social responsibility and did not recognize the importance of fulfilling social responsibilities.

\begin{tabular}{|c|c|c|c|c|c|c|c|c|c|}
\hline Variable & ROA & CSR & Grow & Size & Own & Firs & SGR & Year & Ind \\
\hline ROA & 1.000 & & & & & & & & \\
\hline CSR & $0.028^{*}$ & 1.000 & & & & & & & \\
\hline Grow & -0.016 & $0.184 * * *$ & 1.000 & & & & & & \\
\hline Size & 0.022 & $0.412 * * *$ & $0.359 * * *$ & 1.000 & & & & & \\
\hline Own & $-0.152 * * *$ & $0.102 * * *$ & $0.171 * * *$ & $0.291 * * *$ & 1.000 & & & & \\
\hline Firs & $-0.008^{*}$ & $0.140^{* * *}$ & $0.109 * * *$ & $0.270 * * *$ & $0.226^{* * *}$ & 1.000 & & & \\
\hline SGR & $0.790 * * *$ & -0.003 & $-0.043^{* *}$ & 0.026 & $-0.088 * * *$ & -0.035 & 1.000 & & \\
\hline Year & $-0.040 * *$ & $0.095 * * *$ & 0.009 & $0.057 * *$ & 0.000 & 0.000 & $-0.051 * *$ & 1.000 & \\
\hline Ind & $0.072 * * *$ & $0.050 * *$ & $-0.232 * * *$ & $0.099 * * *$ & $0.046^{* *}$ & $-0.059 * *$ & $0.113 * *$ & 0.006 & 1.000 \\
\hline
\end{tabular}

We also perform a multicollinearity test. Using the variance-expanding factor method, the calculated variance expansion factors are all less than 2 , indicating that there is no multicollinearity between variables.

\subsection{Correlation Analysis}

Table 3. Variable Pearson correlation test 
From Table 3, it can be seen that there is a significant positive correlation between social responsibility and financial performance. Significant test passes at $10 \%$ significance level. The hypothesis H1 is preliminarily verified that social responsibility is positively affecting the financial performance of listed companies. At the same time, there is a significant positive correlation between moderating variables, the growth opportunities as well as scale of firms, and social responsibility. In addition, multiple control variables basically have a correlation relationship at the $1 \%$ or $5 \%$ level, and there is no serious multicollinearity problem, indicating that the selection of control variables is reasonable.

\subsection{Regression Analysis}

(1) Examination of the relationship between social responsibility and financial performance

We use the formula of Model 1 to perform linear regression analysis and test the hypothesis H1 to obtain the following results. See Table 4.

Table 4. Regression analysis of social responsibility and financial performance

\begin{tabular}{ll}
\hline Model 1 & \\
\hline Constant & 0.575 \\
& $(0.210)$ \\
Social Responsibility & $0.010^{* *}$ \\
& $(2.165)$ \\
Nature Of Equity & $-0.014^{* * *}$ \\
& $(-5.505)$ \\
Proportion Of The & $0.000^{* *}$ \\
Largest Shareholder & $(2.022)$ \\
Sustainable Growth Rate & $0.519^{* * *}$ \\
& $(47.023)$ \\
Year & Controlled \\
Industry & Controlled \\
Adj-R & 0.633 \\
$\mathrm{~N}$ & 1353 \\
\hline
\end{tabular}

Note. The t-test value is in parentheses, * indicates a significant level of $0.1, * *$ indicates a significant level of 0.05 , and $* * *$ indicates a significant level of 0.01 . Adj-R2 adjusts $\mathrm{R} 2, \mathrm{~N}$ is the number of samples. Same as below.

From the regression results in Table 4, we can see that there is indeed a positive correlation between social responsibility and financial performance. The higher the social responsibility, the better the company's financial performance, and it is significant at the $5 \%$ level. The hypothesis $\mathrm{H} 1$ is supported. When companies actively take on social responsibilities and take care of the needs of all stakeholders, they can get goodwill from the general public and investors. What's more, expenditures on fulfilling social responsibilities can eventually translate into driving forces for improving economic performance.

(2) Inspection of the regulatory role of growth opportunities and enterprise size between social responsibility and financial performance

In order to verify the role of the two moderator variables of growth opportunity and firm size, this paper first adds growth opportunities and company size, and then joins two interaction terms of social responsibility with growth opportunities and firm size to the formula in MODEL 1. The items are subjected to perform multiple regression. That is, linear regression analysis is performed using the formulas of Model 2 and Model 3, and the hypotheses $\mathrm{H} 2$ and $\mathrm{H} 3$ are tested to obtain the following results. See Table 5. 
Table 5. Regression analysis of growth opportunity, firm size between social responsibility and financial performance

\begin{tabular}{|c|c|c|}
\hline & Model 2 & Model 3 \\
\hline \multirow{2}{*}{ Constant } & 0.547 & 0.284 \\
\hline & $(0.200)$ & $(0.104)$ \\
\hline \multirow{2}{*}{ Social Responsibility } & $0.008^{*}$ & $0.164 * * *$ \\
\hline & $(1.763)$ & $(2.573)$ \\
\hline \multirow{2}{*}{ Growth Opportunity } & 0.001 & -0.004 \\
\hline & $(1.203)$ & $(-0.518)$ \\
\hline \multirow{2}{*}{ Corporate Scale } & 0.00005 & $0.028 * *$ \\
\hline & $(0.049)$ & $(2.459)$ \\
\hline \multicolumn{2}{|l|}{ Growth Opportunity * } & 0.001 \\
\hline \multicolumn{2}{|l|}{ Social Responsibility } & $(0.601)$ \\
\hline \multicolumn{2}{|l|}{ Corporate Scale * } & $-0.007 * *$ \\
\hline \multicolumn{2}{|l|}{ Social Responsibility } & $(-2.460)$ \\
\hline \multirow{2}{*}{ Nature Of Equity } & $-0.014 * * *$ & $-0.014 * * *$ \\
\hline & $(-5.540)$ & $(-5.553)$ \\
\hline Proportion Of The & $0.000 * * *$ & $0.000 * *$ \\
\hline Largest Shareholder & $(1.928)$ & $(1.980)$ \\
\hline \multirow{2}{*}{ Sustainable Growth Rate } & $0.519^{* * *}$ & $0.518^{* * *}$ \\
\hline & $(46.946)$ & $(46.870)$ \\
\hline Year & Controlled & Controlled \\
\hline Industry & Controlled & Controlled \\
\hline $\operatorname{Adj}-R^{2}$ & 0.633 & 0.634 \\
\hline $\mathrm{N}$ & 1353 & 1353 \\
\hline
\end{tabular}

From the regression results in Table 5, it can be seen that in model 2, the $t$ value of the interaction term of growth opportunity and social responsibility is 0.601 , which indicates that the growth opportunity has no significant effect on the adjustment between social responsibility and financial performance. This article assumes that the growth opportunities of listed companies will positively influence the impact of corporate social responsibility on corporate performance. Therefore, Hypothesis 2 has not been verified.

This paper measures the growth opportunities of enterprises by the logarithm of intangible assets. According to research done by some scholars, the intangible resources of enterprises mainly include knowledge resources (Cho, 2005), cultural resources (Hogan, 2014), and reputation resources (Mahon, 2012). Whether it is the accumulation of knowledge resources, the formation of corporate culture, or the establishment of corporate reputation, it is a long-term process. The sample data studied in this paper has a short time span of three years. The regulation effect of intangible assets between social responsibility and corporate performance has not been shown, so, this regulation effect is not significant in Model 3.

In model 3 , the value of the interaction between enterprise scale and social responsibility is -2.460 , which indicates that the negative effect of enterprise scale on social responsibility and financial performance is significant. This article assumes that the scale of listed companies will positively influence the impact of corporate social responsibility on corporate performance. This article does verify that the scale of listed companies can regulate the impact of corporate social responsibility on corporate performance, but the direction of the regulatory role of firm size is opposite to Hypothesis 3. The reason may be that: based on the law of diminishing marginal revenue, when corporate social responsibility investment contributes to the improvement of corporate performance, the company will obtain the maximum marginal revenue when initially investing in social responsibility. As the scale of the company continues to expand, there is a continuous decline in the marginal revenues from corporate social responsibility investments (Qi, 2013). When the scale of a company develops to a certain extent, the company's investment on social responsibility is equal to its marginal revenue, and the company obtains the maximum profit. Since then, the scale of the company keeps on expanding, and companies continue to spend on social responsibility, it will reduce the overall rate of return of the company. Besides, for larger listed companies, the path of corporate social responsibility to influence performance is usually longer. In contrast, there will be a short-term impact on financial performance form social responsibility performed by listed companies with small scales, making the corporate investment in social responsibility investment has a greater effect on corporate performance. This article uses the sample data of listed companies from 2014 to 2016, which is a short run of time. Therefore, the scale of the listed companies is negatively impacting the impact of corporate social responsibility on corporate performance. The scale of the enterprise has 
weakened social responsibility on promotion of financial performance.

\subsection{Robustness Test}

In order to test the robustness of the above research results, this paper further uses the return rate of assets as a proxy variable to measure financial performance and conducts a robustness test. In Model 1, social responsibility and corporate financial performance are significantly positively correlated at the $5 \%$ level, which is consistent with the previous research results. In Model 3, the t-value of the interaction term between growth opportunity and social responsibility is 0.549 , and the growth opportunity has no significant effect on the adjustment between social responsibility and financial performance; the $t$ value of interaction item between enterprise scale and social responsibility is -3.689 . The scale of the company negatively affects the impact of corporate social responsibility on corporate performance. It still supports the previous research results, indicating that the conclusions drawn from the previous research design are reliable. The specific data is shown in Table 6.

Table 6. Robustness analysis

\begin{tabular}{llll}
\hline & Model 1 & Model 2 & Model 3 \\
\hline Constant & 2.539 & 2.607 & 2.251 \\
& $(0.958)$ & $(0.986)$ & $(0.104)$ \\
Social Responsibility & $0.009^{* *}$ & $0.004^{* *}$ & $0.206^{* * *}$ \\
& $(2.182)$ & $(1.925)$ & $(3.360)$ \\
Growth Opportunity & & $0.001^{* *}$ & -0.003 \\
& & $(2.217)$ & $(-0.400)$ \\
Corporate Scale & & $0.002^{* *}$ & $0.037^{* * *}$ \\
Growth Opportunity $*$ & & $(1.780)$ & $(3.331)$ \\
Social Responsibility & & & 0.001 \\
Corporate Scale * & & & $(0.549)$ \\
Social Responsibility & & & $-0.009^{* * *}$ \\
Nature Of Equity & $-0.013^{* * *}$ & $-0.015^{* * *}$ & $(-3.189)$ \\
Proportion Of The & $(-5.540)$ & $(-6.174)$ & $-0.015^{* * *}$ \\
Largest Shareholder & $0.000^{* *}$ & $0.000^{* *}$ & $(-6.192)$ \\
Sustainable Growth Rate & $(2.504)$ & $(2.017)$ & $0.000^{* *}$ \\
Year & $0.494^{* * *}$ & $0.493^{* * *}$ & $(2.100)$ \\
Industry & $(46.168)$ & $(46.162)$ & $0.419^{* * *}$ \\
Adj-R & Controlled & Controlled & $(46.149)$ \\
$\mathrm{N}$ & Controlled & Controlled & Controlled \\
\hline & 0.625 & 0.627 & Controlled \\
\hline
\end{tabular}

\section{Conclusion}

This article regards 451 Chinese listed companies from 2014 to 2016 as the research object, uses scores from the third party RLCCW to measure the social responsibility of companies, analyzes the sample data, and explores the relationship between social responsibility and corporate performance. The results of empirical research show that, first, the social responsibility performance of listed companies in China is of great difference, and the average disclosure degree of social responsibility information is low. Second, there is a significant positive correlation between corporate social responsibility and financial performance. The better corporate social responsibility performance, the higher the level of economic performance. Third, given the long-term and cumulative nature of intangible resources as indicators for measuring growth opportunities, the time span covered in this study is too short. So there is not a significant regulatory effect of corporate growth opportunities between social responsibility and financial performance. Fourth, the scale of the company has a counter-regulatory effect between corporate social responsibility and economic performance. That is, the smaller the listed companies perform social responsibility, the easier it is to obtain economic returns.

This article enriches and supports research that there is a positive correlation between social responsibility and corporate financial performance. Furthermore, on the choice of indicators, many scholars have designed their own indicators system and used content analysis methods, reputation methods and so on to quantify corporate social responsibility performance. This paper utilizes the scores of independent third-party social responsibility rating agencies as a measure of social responsibility. This is beneficial to avoid the subjective impact that 
individuals may have on the measurement of indicators. China's social responsibility rating agency system is more and more mature, and the third-party agency rating method will bring more objective and comprehensive indicator data for the study of social responsibility. Second, most studies regard the size of a company as a control variable. This paper uses it as a regulatory variable and finds that firm scale performs a counter-regulation effect between corporate social responsibility and financial performance. In addition, very few scholars have attempted to study the impact of growth opportunities on corporate social responsibility and performance. This article assumes that corporate growth opportunities play a positive regulatory role, although this hypothesis is not available in the sample data of listed companies from 2014 to 2016. It is confirmed that researchers can consider the growth opportunity variable of intangible assets in the discussion of the longer-term impact of social responsibility.

For listed companies, good social responsibility performance is conducive to the growth of financial performance. Nowadays, the popularity of the Internet has made it easier for the public to gain information about the fulfillment of corporate social responsibilities. When managers make decisions to improve economic performance, they should incorporate the social responsibility factor into the company's daily system. They need to combine social responsibility fulfillment with development strategy and actively undertake social responsibilities related to their business operations. For the government, it is necessary to further improve relevant laws and regulations to supervise corporate responsibility behavior. The government is supposed to issue related policies to ensure that the companies undertake basic social responsibility. At the same time, incentives such as tax exemptions and liberalization of bank loan conditions are helpful to stimulate and encourage domestic companies to fulfill their social responsibilities. Also, government should severely punish those companies that fails to take social responsibility. For society, multiple participation in supervision can more effectively guarantee corporate social responsibility. There is a need to establish a comprehensive corporate social responsibility monitoring system that consists of companies, governments, and society.

Due to the limitation on availability of data and personal knowledge, the following limitations exist in this study. First, this paper examines its impact on corporate performance from the perspective of the whole social responsibility. It has not yet explored how segmented stakeholder groups influence the process where corporate social responsibility fulfillment affects financial performance. Second, we use only three years of data to test the relationship between social responsibility and economic performance. The observation period can be appropriately extended to discuss the role of the variables' effect respectively in the long-term and short-term. Third, this paper only studies the one-way impact of social responsibility on financial performance, and does not consider whether the performance of financial performance affects the fulfillment of social responsibility. In the future, we can do further research on the synergy between the two.

\section{References}

Andonova, V. (2016). The Role of Industry Factors and Intangible Assets in Company Performance in Colombia. Journal of Business Research, 69(10), 4377-4384. https://doi.org/10.1016/j.jbusres.2016.03.060

Bi, J. (2015). Is Social Responsibility Report Affecting The Performance of Refinancing Companies? —Evidence From Chinese Listed Companies. Investment Research, (4), 46-63.

Chen, C. (2012). Study on Influence of Corporate Social Responsibility on Competitive Advantage based on Intangible Resources. Huazhong University of Science and Technology.

Cheng, B., Ioannou, I., \& Serafeim, G. (2014). Corporate Social Responsibility and Access to Finance. Strategic Management Journal, 35(1), 1-23. https://doi.org/10.1002/smj.2131

Chi, W. (2011). Empirical Analysis on the Relation Between Enterprises' Social Responsibility and Financial Performances-Based on The Unlisted Enterprises in S Province. Shandong University.

Cho, H. J., \& Pucik, V. (2005). Relationship Between Innovativeness, Quality, Growth, Profitability, And Market Value. Strategic Management Journal, 26(6), 555-575. https://doi.org/10.1002/smj.461

Corporate Social Responsibility in China. (2017). "2016 china's top ten corporate social responsibility (domestic)" authority released. Retrieved http://www.csr-china.net/a/guandian/pinglun/2018/0126/4199.html

Eunice. (2014). Corporate Social Responsibility as a Marketing Strategy for Enhanced Performance in the Nigerian Banking Industry: A Granger Causality Approach. Procedia-Social and Behavioral Sciences, 164(31), 141-149. https://doi.org/10.1016/j.sbspro.2014.11.062

Guo, Y. K., Wang, Y., \& Liu, X. (2014). Nature of Property Rights, Managerial Ownership and Social 
Responsibility Information Disclosure-Evidence from Chinese Listed Companies. Economics and Management Research, (9), 114-120. https://doi.org/10.13502/j.cnki.issn1000-7636.2014.09.014

Hogan, S. J. (2014). Organizational Culture, Innovation, And Performance: A Test of Schein's Model. Journal of Business Research, 67(8), 1609-1621. https://doi.org/10.1016/j.jbusres.2013.09.007

Jiang, Y. (2011). Market Reaction to the Disclosure of Corporate Social Responsibility Information-Based on the Event Study of the Issuance of Chinese Listing Company's Social Responsibility Reports. Economic and Management Research, (8), 123-128. https://doi.org/10.13502/j.cnki.issn1000-7636.2011.08.010.

Kotonen, U. (2009). Formal Corporate Social Responsibility Reporting in Finnish Listed Companies. Journal of Applied Accounting Research, 10(3), 176-207. https://doi.org/10.1108/09675420911006406

Li, S. (2013). Can Corporate Social Responsibility Report Reduce Cost of Equity Capital?-Evidence from $\begin{array}{lllll}\text { Chinese Stock } \quad \text { Market. } & \text { Accounting }\end{array}$ https://doi.org/10.3969/j.issn.1003-2886.2013.09.009

Liu, J., \& Wang, J. (2012). Corporate Social Responsibility and Capital Constraints-Evidence From The Listed $\begin{array}{lllll}\text { Companies Of China. } & \text { Management }\end{array}$ https://doi.org/10.14120/j.cnki.cn11-5057/f.2012.11.009

Luo, X. (2009). The Debate over Doing Good: Corporate Social Performance, Strategic Marketing Levers, and Firm-Idiosyncratic Risk. Journal of Marketing, 73(6), 198-213. https://doi.org/10.1509/jmkg.73.6.198

Mahon, J. (2012). Corporate Social Performance Profiling: Using Multiple Stakeholder Perceptions to Assess a Corporate Reputation. Journal of Public Affairs, 12(1), 12-28. https://doi.org/10.1002/pa.433

Marc, O. (2012). Assessing Stakeholder Satisfaction: Toward a Supplemental Measure of Corporate Social Performance as Reputation. Corporate Reputation Review, 15(2), 119-137. https://doi.org/10.1057/crr.2012.3

Nanggong, A. (2016). The Effect of Intangible Resources on Innovation in Service Firms with the Role of Absorptive Capacity as a Moderating Variable. IEEE International Conference on Management of Innovation \& Technology, (1), 7-12. https://doi.org/10.1109/icmit.2016.7604999

Qi, W. (2013). Empirical Study the Influence of Corporate Social Responsibility on Corporate Performance-Analysis the Listed Companies of Food. Technical Economics and Management Research, (8), 3-13.

Ren, B. (2017). An Empirical Analysis of the Relevance of Corporate Social Responsibility and Financial Performance: A Case Study of Shanghai and Shenzhen Real Estate Listed Companies. Journal of Hebei University of Economics (Humanities and Social Sciences), 14(7), 46-48.

Shi, X. (2000). Re-understanding of Intangible Assets in Western Accounting Theory. Productivity Research, (1), 26-27. https://doi.org/10.19374/j.cnki.14-1145/f.2000.z1.010

Sina Technology. (2016). Note 7 blasts hit the stock market Samsung's share price hit the biggest drop since 2012. Retrieved from http://tech.sina.com.cn/t/2016-09-12/doc-ifxvukhx4922031.shtml

Tao, W. (2012). The Relationship Among Corporate Social Responsibility Disclosure, Media Exposure And Corporate Financial Performance. Chinese Journal of Management, 9(8), 1225-1232.

Waddock, S. A., \& Graves, S. B. (2015). The Corporate Social Performance-Financial Performance Link. Strategic Management Journal, 18(4), 303-319. https://doi.org/10.2139/ssrn.306599

Wang, H., \& Song, T. (2007). The Relationship Between Corporate Social Responsibility And Performing: Empirical Evidence From The Listed Companies Belonging To 180 Indices Of Shanghai Securities Exchanges. Journal of Nanjing Normal University (Social Sciences), (2), 58-62.

Wang, L. (2011). Corporate Social Responsibility in the Chinese Forest Industry: Understanding Multiple Stakeholder Perceptions. Corporate Social Responsibility and Environmental Management, 20(3), 129-145. https://doi.org/10.1002/csr.286

Wen, S. (2008). An Empirical Research on Relationship between Corporate Social Responsibility and Financial Performance-Analysis Based on Stakeholder Theory and Panel Dates. China Industrial Economics, (10), 150-160. https://doi.org/10.19581/j.cnki.ciejournal.2008.10.015

Xia, S. (2016). Research on Relationship between Environmental and Financial Performance of Listed Chemical Manufacturing Companies. Environmental Science and Management, 41(12), 162-167. 
Yu, H. (2015). The Relationship between Corporate Social Responsibility and Corporate Performance, the Moderating Role of Enterprises' Social Capital. Management Review, 27(1), 169-180. https://doi.org/10.14120/j.cnki.cn11-5057/f.2015.01.016

Zeng, F. (2012). A Research on Building the Performance Management Model Based on the Corporation Competitive Advantage Promoting - Taking A for Example. Suzhou University.

Zhang, J. (2012). The Study on Relationship between Corporate Social Responsibility and Financial Performance-Based on Listed Companies' Historical Data from 2007 to 2011 in Northeast China. Dongbei University of Finance and Economics.

Zhang, L. (2011). An Empirical Research on the Effect of CSR on CFP Based on Listed Companies in China. Journal of Northeastern University (Natural Science), 32(2), 292-296.

Zhang, Q. (2014). The Relationship between the Quality of the Social Responsibility Information Disclosure and the Financial Performance of Listed Companies in China-An Empirical Research Based on the Analysis of the Corporate Social Responsibility Report Ratings 2010-2011 by Rankings CSR Ratings. Journal of Guangdong University of Petrochemical Technology, 24(1), 81-85.

Zhang, Y. (2016). Study on the Relationship between Environmental Investment and Economic Performance-Empirical Evidence Based on the Science and Technology Enterprise. Journal of Industrial Technological Economics, 35(1), 111-121. https://doi.org/10.3969/j.issn.1004-910X.2016.01.014

Zhong, R. Q. (2013). The Bearing of the Cost for Corporate Social Responsibility in the Legal Perspective. Journal of Xiamen University (Arts \& Social Sciences), (1), 140-148.

\section{Copyrights}

Copyright for this article is retained by the author(s), with first publication rights granted to the journal.

This is an open-access article distributed under the terms and conditions of the Creative Commons Attribution license (http://creativecommons.org/licenses/by/4.0/). 